\title{
Faut-il brûler ... or Isn't There \\ a Way to Read Claudel Now?
}

\author{
Martha Walker \\ Mary Baldwin College (Staunton, Virginia)
}

$L^{\prime}$ Échange: the title of Claudel's 1913 play, rewritten for a new production in1955, makes clear the most important element of the story: a wild young man agrees to trade his wife to a rich older man for money and, more importantly, independence. This immoral exchange can only be a counterexample to show the impossibility of ideal marriage on earth. Or so a reading in keeping with conventional criticism of Claudel's oeuvre would present the primary focus of the drama. Traditionally, of course, critics have linked Claudel's famous Christmas Eve epiphany in Notre Dame and his early affair with a married woman to his theater, especially L'Échange, Partage de Midi, and Le Soulier de satin. Claudel somehow seems to have remained immune to the celebrated death of the author. The bartering of a bride is not, however, the only exchange that occurs in L'Échange, nor is the story of Claudel's life and faith the only prism through which to read the work. I am proposing a rereading of $L$ 'Échange as one example of the ability of Claudel's work to go beyond the facts of his life and the faith that characterized it. While I would not want to present a misreading that denies these facts, I intend to focus on the exchange of not only spouses but identities in this play that makes it as a provocative in a Postmodern context as it was at its original High Modern moment of production.

The plot is based on conventional representations of gender. Two very different types of women are married to two very different types of men. One woman is good, sincere, genuine; the other is bad, cruel, deceptive: an actress. The first woman is married to a poor, weak, immature man. The second is married to a rich, greedy, willful man. The poor man sells his good wife to the rich man because he wants money and freedom, and because he has slept with the rich man's bad wife. The rich man is tired of his bad wife and attracted to the good girl. A Christian fable of the sanctity of marriage? Clearly - the poor weak man dies violently and the rich man loses all his money. 
Yet these four characters tell an important story about 'women's' identity on stage and about that very postmodern notion: the performativity of gender. Identities are swapped along with wives, and the circulation of the commodity 'gender traits' in this particular theatrical context is hardly conventional. As characters change partners and life circumstances here, the play's apparently obvious gender constructs are upset. The very fixed identities that define the implicit moral fabric of the story are in fact fluid. Could this play not simply be about Christian virtue and the impossibility of true spiritual union between a man \& a woman but also about decentered subjects and the inherent multiplicity of individual identity? Could even Claudel, that hoary, right-wing, fascist-sympathizing, ultra-conservative, devout Catholic have produced a play that speaks to difficult contemporary questions about identity?

In Gender Trouble, Judith Butler posits her theory of the performativity of gender, the ways in which common 'womanly' or 'manly' behavior is not an essential component of biological sexual identity but behavior learned from a society that expects humans to 'perform' in sexappropriate ways. Because such behaviors are perceived as emanating from the individual, there is no isolated social laboratory in which to investigate how gender is constructed. To quote Butler:

[...] acts and gestures, articulated and enacted desires create the illusion of an interior and organizing gender core $[\ldots]$.

If the "cause" of desire, gesture, and act can be localized within the "self" of the actor, then the political regulations

and disciplinary practices which produce that ostensibly coherent gender are effectively displaced from view.

The displacement of a political and discursive origin of gender identity onto a psychological "core" precludes an analysis of the political constitution of the gendered subject [...] (136).

Obvious examples such as drag shows, Butler goes on to say, subvert what we have internalized about appropriate gender performance and may permit consideration of less blatant modes of gender performance. I am interested in thinking about what it means, almost literally, to perform 
gender because, I would argue, theater is one venue that does allow "analysis of the political constitution of the gendered subject." As semiotic studies of theater by Ubersfeld, DeMarinis, Fischer-Lichte1 and others make clear, comprehension of theatrical sign systems requires spectators to draw on their knowledge of the world of the play and the reality they know outside the theater. By virtue of the fact that the spectacle creates its own closed society, the play requires spectators to define for themselves, in concert with or perhaps in opposition to the 'reality' they know, what it means to be a 'man' or a 'woman' in a particular performance context. Thus, a space is created where a (microcosmic) society's constitution of gender roles can be analyzed.

Of course, $L^{\prime} E$ Échange predates Butler and literary analyses of the text have followed other theoretical paths. Critics have been almost unanimous in describing the four characters as common types or even archetypes that evoke Claudel's life experience. Implicitly these metaphorical readings of the characters work because they depend on the association of traditionally masculine and feminine character traits with particular abstract principles. Thus, for example, Nagy (26) and Villani (75) equate the long-suffering Marthe with Mary and the Church . Waters sees Thomas Pollock Nageoire as the embodiment of nouveau riche America (99), and Louis Laine is "untamed, uncivilized nature" (Villani 75). "Les personnages sont fort campés. Ce sont des véritables types, " one critic writes (Mercier-Campiche 108). The fundamental sketches of these characters are not inaccurate, but they overlook another important exchange at issue here.

Despite the apparent character types, gender identity is not necessarily static as the men and women on stage display traits often associated with the other gender. The play defines its own appropriate gender roles as relationships among the two couples dissolve and are reconstituted. Discussions of marriage and betrayal present prescriptions for men's and women's behavior, but paradoxically Marthe, Louis, Lechy, and Thomas do not exemplify these behaviors or even their counterexamples. In fact, the characters' behavior often subverts the definitions of gender identity that the text itself creates. This exchange of gender identity is often most readily identifiable at moments of subtle exchange in the plot, those moments of trade-offs among the characters that are secondary to Louis' primary exchange of his wife Marthe for money. It is the figure of Lechy, arguably a minor player in the principle exchange of the story, who negotiates many of what I call these secondary exchanges and 
in so doing opens up the possibility for gender roles to be exchanged.

The conventional commentary on the play that I have already mentioned cites Lechy as a typical femme fatale (Villani 75) and even as the on-stage representation of theater itself (Waters 99). Each of those is a telling characterization from my point of view because Lechy herself has a lot to say about what a femme, fatale or otherwise, does - how she acts. To say that Lechy embodies the theater and therefore artifice, dissimulation, untruth and all those other prevaricating traits Western tradition has associated with women as well as theater, is to look at only one aspect of the role Lechy plays as this play's 'villainess'. In L'Échange what Lechy says and how she acts, how she performs throughout the play, are crucial to the play's definition of what it is to be a woman. While her words establish a certain gender norm, the manipulative trade-offs she arranges to get what she wants often put the others into positions where sex and gender do not coincide. Most importantly, Lechy's definitive statements on women's role and behavior are an attempt to define her rival Marthe. The question becomes, though, whether or not, per Lechy, Marthe can or should be defined as a woman. Consequently Louis' identity is at stake also. Lechy's cool performance in this series of spousal exchanges may not be as explicitly about defining Louis' nature as it is about defining Marthe's, but the ultimate effect is perhaps even sharper. Louis, too, is defined by an exterior notion of what it is to be a man. Paradoxically, though, the definitions meant to serve as ideals for the wild manchild and the sacrificing wife only serve to point out their inability to play their assigned parts. Marthe may not be who Lechy says she is but Louis becomes what Lechy makes him. Her words and deeds are part of an accomplished performance that is instructive for both her on- and offstage audience.

In the same way that Lechy offers both explicit and implicit illustration of what it means to be a woman in this context, she offers the same implicit and explicit definition of theater. She speaks of her career and her work and engages in both deliberate and unconscious role-play that reiterates her conception of performance. Through Lechy's personal 'act' the co-incidence between gender and theater, Butler's performativity of gender, in en-acted.

The first hints of the performance to come are clear in Lechy's first encounter with Marthe in Act I. Lechy is assessing the exchange of lovers she had convinced Louis to make the night before and taking stock of Louis's wife. Her conclusion: "Vous êtes une femme étrange" (751). 
While she is referring to Marthe's reticent character and domestic diligence, her conclusion seems to beg the question of what the norms of feminine behavior will be here. In fact, Lechy's analysis of Marthe's character might be an element of the research she is doing for a role she soon will be acting, that of Marthe herself. It is not enough for Lechy simply to replace Marthe as Louis' lover, she wants to take over Marthe's role, to become the other woman, to insure that she can be to Louis all that Marthe was to him, or more - a better Marthe.

For Lechy performance is power over the audience, and she is determined to perform the role of Louis's new lover so well that Marthe will be not only powerless but effectively erased. Marthe will be not a femme étrange but not a femme at all because Lechy is determined to humiliate her and to deprive her of the role she once had. In an effort to add insult to the injury of infidelity, Lechy pointedly tells Marthe how Louis has talked about her to his new lover, using Louis's nickname for Marthe in the process. "Bonjour, Douce-Amère ! Tu vois, je connais ton nom. Il me raconte tout [...]" (764). Lechy usurps Marthe's role as intimate partner and confidante to make the other woman disappear as a woman and also to make herself appear because Lechy can only perform femininity. She doesn't seem to have any gender identity, as this play defines it, of her own. She flaunts her art to the others by explaining that "il y a tant de femmes en moi" (777) and going on to elaborate the many different types of woman she has portrayed, but who Lechy herself is is left unsaid. There is no 'real' Lechy, only performance.

And even Marthe is forced to admit that Lechy is a good performer as the later version of the play makes explicit:

Lechy : [Montrant Marthe] Voulez-vous que je vous joue son role? Je le jouerai mieux qu'elle.

Marthe: Vous savez être Marthe plus que moi.

Lechy : Pas plus. Mieux. Avec du recul.

C'est mon métier.

Ce garçon, il fallait bien que je lui fournisse ce qu'il demandait. Il vous aime, vous savez! (777)

Lechy knows more about Marthe than Marthe herself because she has studied what it means to be a woman. Her professional talent and prepa- 
ration enable her to give Louis what he (thinks) he wants - that which Marthe apparently is not: a woman. Lechy knows that Marthe and Louis do not have her knowledge of the stage. Unable to play the roles they are used to playing, man and woman, they will be left at a loss, and Lechy will be in control of the series of exchanges she has designed to consolidate her control, more important to her than a conventional role as a dutiful woman.

The notion of Lechy's métier is an important one for gender definition in L'Echange because work is what separates the men from the women. "Chez nous," Thomas Pollack Nageoire tells Marthe early in the play, "les femmes ne travaillent pas" (741). Lechy, though, has a métier, and paradoxically, it is only though her profession that she can be a woman. Marthe, too, is unwomanly by Thomas Pollack's definition. It is not simply the fact that she does the hard domestic work to which he is literally referring in the first act of the play. Marthe's job, as she herself explains it, is Louis while Louis has no job. Who, then, are the women here? Thomas Pollack's role is clear. "J'ai fait toutes sortes de jobs" (740). He must be a man. Louis, on the other hand, is equally forthright about the fact that he doesn't work. "Moi je ne fais rien de tout le jour" (732). He is not only incapable of being a breadwinner he is also incapable of doing his other job as a man, being a faithful husband to Marthe. "L'homme a des devoirs. J'ai pris des devoirs envers toi. [...] Mais je ne puis pas les remplir. [...] Je n'aurai point de part aux occupations des hommes» (687). Marthe, though, cannot accept so readily Louis's abnegation of his responsibility and his masculine role. « Pourquoi est-ce que tu ne réussis pas à être un homme?» (762).

The answer to this question brings us back to Lechy and her part as the femme fatale and back to the play's own counterexamples to its gender paradigms. Lechy infantilizes her new conquest, calling him "mon enfant" and "bébé" (764). It seems almost redundant to point out that Louis's powerlessness ties into the presence of this dominating woman the boy fearing castration before the phallic mother. Lechy's métier as an actor not only allows her to create a simulacrum of gender identity for her herself, it also insures that she can be instrumental in defining Marthe's and Louis's gender roles as well. "C'est son job la réalité?" Marthe asks about Lechy (778). Her question goes unanswered in the text, but the spectacle reminds us that doing the work of theater all but precludes reality, exchanging it for a constructed simulacrum of real life.

Lechy's determination to control Marthe's and Louis' reality can- 
not, of course, be divorced from her own insecurity and need for an audience for her performance. She knows Louis will leave her as easily as he left Marthe and she cannot stand the threat of abandonment, so she makes threats herself. Should Louis leave, her jealous African-American servant will surely kill him. It is important to Lechy, though, that her revenge be couched in the terms of her assumption of Marthe's identity and role as a woman. She taunts Marthe for not doing more to keep her husband because as Lechy defines womanhood explicitly in the earlier version of the play, "Vous n'êtes pas une femme si vous n'avez pas envie de vous venger" (703). Marthe, then, is once again unwomanly but Lechy more than makes up for it, playing the part of the model woman. "Ne t'aije bien vengée?" Lechy asks her opposite number after she has engineered Louis' death (792). Somehow Lechy justifies murder in the name of playing a part, the passionate woman.

In the aftermath of Louis's death, his paradoxical gender identity is also at issue. Marthe, who has accepted Lechy's usurpation of her role, is also prepared to admit that Louis has lost not only his life but his sense of self to his involvement with Lechy. As Marthe mourns over the dead body, she covers Louis' face with her scarf, which he had taken earlier as a parting souvenir. It is, of course, a gesture of respect but also a reiteration of Louis's erasure from the action of the play, of the erasure of his identity. He is hidden away, out of sight; he cannot witness the final exchange that takes place as Marthe tacitly agrees to a relationship with Thomas Pollack Nageoire, now impoverished and thus perhaps no longer a man as he has always understood the concept. This shift in gender identity also comes about as a result of Lechy's machinations. She is the one who has set fire to his wooden house, knowing it contained all the papers that established his wealth. She emasculates Thomas Pollack Nageoire with as little effort as she emasculated Louis Laine.

Thanks to Lechy, Thomas Pollack Nageoire must exchange wealth for poverty, and Louis Laine has exchanged his life for satisfaction of momentary passion. What I have called the play's secondary exchanges that reconfigure Marthe's gender identity operate somewhat les obviously, though. In 1955 Claudel exchanged a new version of the text for the original to mark a new production by director Jean-Louis Barrault. This later version demonstrates the exchange of Marthe's identity exceptionally well in pone of the most obvious and often discussed changes from the first to the second version. Originally Act III begins with a soliloquy in which Marthe makes an impassioned demand for justice. That act in the 
second version begins with her rereading letters she has just written to her parents and to her priest at home. If the letters do not actually lie, they euphemistically skirt the horrible truth of the exchange into which her husband has entered the couple. She veils the truth because she does not want to reveal weakness and failure, and the exchange of speech for writing from one version to the next underscores the notion of a certain 'masculinization' of Marthe's identity. By writing, Marthe inscribes herself in a tradition of power and of order, of domination and of superiority. By writing she creates that which does not exist in her life. By writing Marthe can create a simulated identity, assume a role, just as Lechy does through acting. Written expression has a symbolic gendered resonance as a way of reifying speech, the point of entry into the realm of Law, of the Father. Interestingly, inherent in womanhood as Lechy plays it is a certain lawlessness as if she would defy the necessity of entering the realm of the Symbolic as she performs women's parts. "Je suis sans règle et sans loi" she maintains in the first version (696).

Marthe's letter writing is one of two distinct departures from the original text in the second version. The other key difference is that it is clear that Marthe, abandoned and bartered away by her husband, is pregnant. Given the ways in which Marthe contradicts the notion of womanhood as it is spelled out in the play, I am tempted to read her pregnancy not as a mark of some constructed version of maternal woman but as a reiteration simply of her biological sex - female - that stands in opposition to the contorted representations of gender played out in L'Echange. Lechy tries to make of Marthe's pregnancy a motive for Marthe to keep Louis, but Marthe herself does not mention it, does not play this womanly part that she could logically perform to her advantage. She continually refuses to allow her context to define her gender identity.

While the play concludes by effecting the exchange that was planned from the beginning, Marthe's pairing with Thomas Pollack Nageoire, this exchange is not what it appears to be because of the exchange of gendered traits and identities that has occurred. The couple who remain at the end of the action are a male who has lost his money and thus his influence and power and a female who has found a voice in writing and refused to let her identity be dictated to her. It is as if the only couple remaining at the end of the play's action consists of a non-man and a non-woman. Lechy, too, appears to end up as a gender-less entity. Her agency, instrumental in bringing TPN and Marthe to the point where they end up, doesn't survive without the conventional man/woman, 
Louis/Marthe couple as its focus. By the end of L'Echange, Lechy is deflated, bereft of any identity, constructed, performed or metaphorical.

As Marthe and TPN take hands and exit the stage at the end of the play, the suggestion is of a new relationship characterized by the exchange of conventional gender roles for individual identity that has just occurred. The text demonstrates its capacity to exchange a portrayal of the impossibility of the ideal of the sacrament of marriage for a reading of representations of gender and its constitution.

\section{Notes}

1 See, for example, Anne Ubersfeld, Lire le théâtre and L'Ecole du spectateur; Marco DeMarinis, The Semiotics of Performance, and Erika Fischer-Lichte The Semiotics of Theater.

\section{Works Cited}

Butler, Judith. Gender Trouble:Feminism and the Subversion of Identity. New York: Routledge, 1990.

Claudel, Paul. L’Échange (deuxième version). Théâtre. Vol.1. Paris: PléiadeGallimard, 1992.

DeMarinis, Marco. The Semiotics of Performance. Trans. Aine O'Healy. Bloomington: Indiana UP, 1993.

Fischer-Lichte, Erika. The Semiotics of Theater. Trans. Jeremy Gaines and Doris L. Jones. Bloomington: Indiana UP, 1992.

Mercier-Campiche, Marianne. Le Théâtre de Claudel ou la puissance du grief et de la passion. Paris :Jean-Jacques Pauvert, 1968.

Nagy, Moses M. "A Young Diplomat Looks at America:L'Échange." Claudel Studies 11 (1984): 24-31.

Ubersfeld, Anne. Lire le théâtre, fourth ed. Paris : Editions sociales, 1993.

Villani, Sergio. "L'Échange, Claudel's First Hymn to 'Totality". Claudel Studies 18 (1991): 74-77.

Waters, Harold A. “A propos de la seconde version de l'Echange." La Revue des lettres modernes 114-116 (1965): 95-109. 